\title{
One Giant LEAP for All
}

\author{
Developing and implementing a community \\ non-profit and legal partnership to overcome \\ barriers to re-entry
}

CARRIE HAGAN AND KYLE LANHAM

\section{ABSTRACT}

A criminal record is an anchor that stays with you even after you have paid your debt to society for the crime you committed. That record can make it nearly impossible to meet basic needs, especially housing, employment, and education. To assist in meeting these needs, Goodwill of Central and Southern Indiana and the Civil Practice Clinic of the Indiana University Robert $H$. McKinney School of Law partnered to create the Legal Expungement Advice Program to give qualifying individuals a second chance. This article examines the intersection of these two Indianapolis-area programs providing resources for employment and expungement that help persons previously charged with or convicted of crimes get back on their feet -- and stay that way.

Once you have a criminal record for any reason, serve your time, and pay your restitution, you are discharged back into society, often without the skills or support network that you need, and now with a criminal history. This criminal history stays with you; it stays with you because society worries that you will offend again and wants to make sure that you are punished for certain patterns of behavior and suffer the consequences of your actions. Your criminal history also stays with you to put employers on notice of your prior acts, so they can protect themselves from liability for your future bad actions and protect others that may come into contact with you should you be hired as one of their employees. This article explores a community partnership intended to overcome a significant barrier to reentry in five sections: The Problem, The Partners, The Population Being Served, The Partnership and Project, and The Reach. The article will look at how specific employment practices, programs, and legal partnerships create avenues that go beyond helping someone get basic employment. 


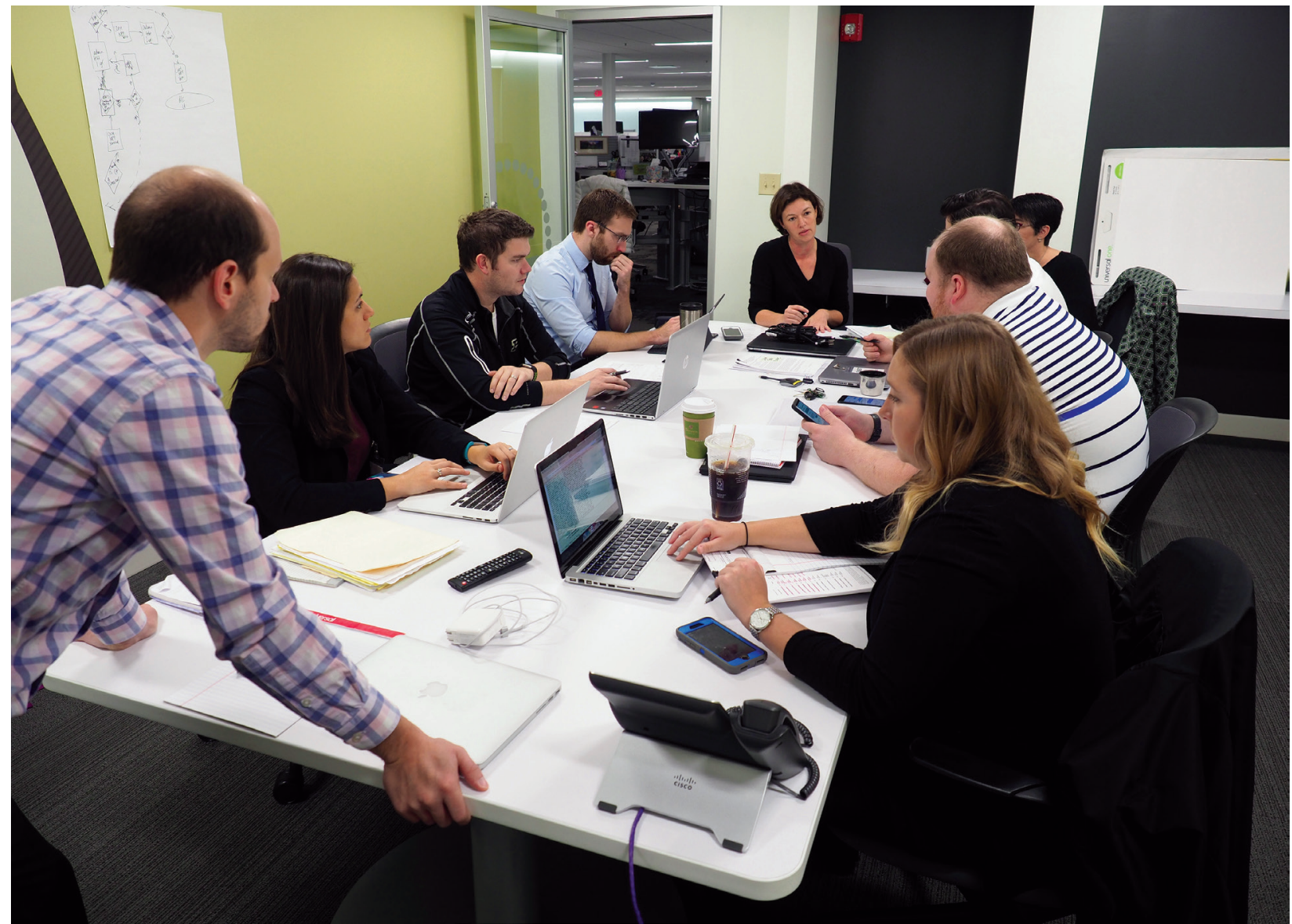

Civil Practice Clinic students and Carrie Hagan hold LEAP expungement clinic at the Goodwill corporate offices. Photo credit: David H Jaynes

\section{THE PROBLEM}

Research by the National Employment Law Project (NELP) has shown that there are an astounding number of Americans, around 70 million, who have a prior arrest or conviction record (2018). This amounts to nearly one in three adults in the U.S. These Persons with a Criminal Record ${ }^{1}$ (PCR) - that criminal record possibly containing both arrests not leading to charges being filed and charges resulting in convictions are often unemployed or underemployed because their criminal record does not allow them to get past the job application stage. The question "Have you ever been convicted of a crime?" seems harmless when one has never committed a crime, but for individuals who do have a criminal record, this disclosure closes many doors before they can truly be opened (Rodriguez \& Emsellem, 2011). As a result, one's criminal record usually precludes any offer of employment, unless he or she is able to find work at a company with a focus on hiring and assisting persons who have formerly been incarcerated.

In 2013, Indiana signed the Second Chance

\footnotetext{
${ }^{1}$ For this paper, the authors are choosing to refer to the population that they assist as "persons with a criminal record"(PCR) instead of referring to them generally as "ex-offenders," as many of the individuals impacted by this community partnership may not have actual convictions on their record, and instead only charges that didn't lead to a conviction.
} 
Law, which allows for PCR to have their criminal records expunged. Expungement, or "expungement of record," is generally defined as "the removal of a conviction ([especially] for a first offense) from a person's criminal record," (Garner \& Black, 2014). Expungements are often said to "seal" one's criminal history records, and sealing means that no one has access to those records nor can pull them in any records search for a background check (Justia, 2018). Expungement in Indiana under this law does not mean that the records are destroyed but rather that access to these records is limited to only certain state agencies. Depending on the type of crime that was expunged, crimes may still appear on one's record as "marked as expunged." With the advent of the Second Chance Law, PCR had a legal opportunity to clear their past, and should they be successful, move into better employment and educational options. In Marion County, Indiana, since July 2013, near 11,500 expungement petitions have been filed and reviewed by the Marion County Prosecutor's Office, and 60 percent of those petitions involved convictions (Blinder, 2018).

Indiana's law is broad given the scope of what may be expunged and how often. Other states' laws are more restrictive as to what and how records may be expunged. With regards to federal crimes, there is currently no statute allowing federal convictions to be expunged. Additionally, there is varying ability by jurisdiction to access expunged records once they have been expunged (CCRC Staff, 2016). In Indiana for example, even after one has their criminal conviction records expunged, should they be charged later in time with a crime similar to the one(s) previously expunged, the prosecutor can seek to admit prior

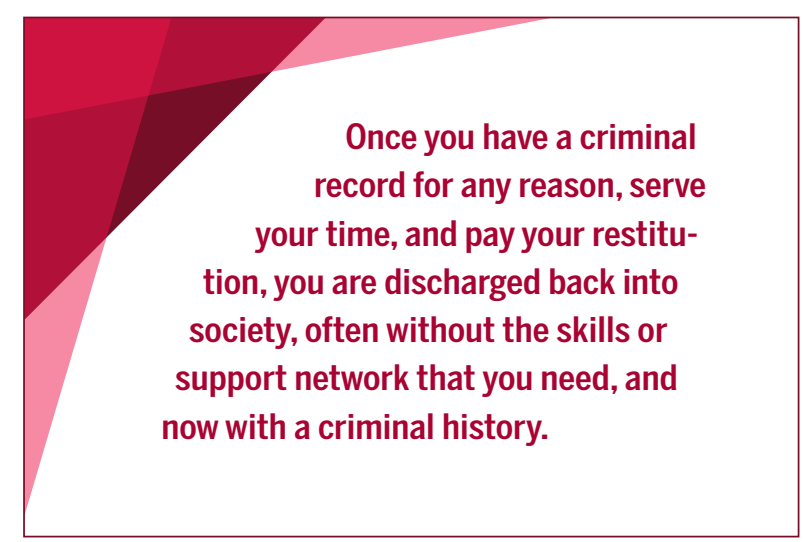

history as evidence in the pending case (Ind. Code $\S 35-38-9-6(d))$. This sort of situation leads to questioning the value of getting an expungement, especially when expunged records can later be reopened and used against them. However, this request to reopen expunged case material is not extensively used, if at all, at the current time (Fogle, 2018).

In Indiana, one may expunge five "categories" of crimes from one's criminal record: arrests/ dismissed charges; misdemeanors; D felonies; A, B, C, and D Felonies without Serious Bodily Injury; and A, B, C, and D Felonies with Serious Bodily Injury $^{2}$ (Digest for Court Staff and Clerks, 2017). Each category of crime has its own requirements and restrictions about how and when one may file to have a record expunged (Ind. Code $\S \S 35-38-9-1$ - 35-38-9-11). Hoosiers ${ }^{3}$ seeking to expunge their records may seek to have arrests and dismissed cases expunged as many times as needed during their lifetime under the current law, but may only seek to have their records of convictions expunged once in their lifetime (Ind. Code § 35-38-9-9(i)).

In addition to various restrictions and hurdles one must satisfy in order to expunge, there are

\footnotetext{
${ }^{2}$ All A, B, C, and D felonies were recategorized as F1-F6 felonies in 2014 (2014 Ind. HEA 1006).

${ }^{3}$ Hoosiers is a colloquial term for Indiana residents.
} 
several crimes that are completely precluded from the possibility of expungement, such as murder, trafficking, sex offense crimes, and crimes involving child molestation (Ind. Code § 35-38-9-3(b)). As one might expect, for eligible convictions, the more serious the crime one is seeking to expunge, the more hurdles there are to cross, and the more risk is involved (at least in Indiana) that your request may not be granted.

Once records are expunged, the next question is how that person should answer questions on a job application pertaining to criminal history and convictions. Questions on job applications such as "Have you ever been convicted of a crime?" seem harmless when someone has no criminal history. The same scenario is trickier when it is from the perspective of one who has both been convicted of a crime and had it expunged. If one checks "yes," even though records of said convictions no longer appear in public record, one may lose any chance at that job because they checked "yes." Should they check "no" and somehow the prospective employer learn that they have such a past, even though the records have been expunged, they run the risk of not getting the position for alleged dishonesty. Given all of the above, multiple questions thus arise when looking at expungement for PCR: How may I obtain expungement? Am I eligible for expungement? If not, why not? If yes, how do I go about obtaining expungement? And if I successfully obtain expungement, what does that mean for the future?

\section{THE PARTNERS}

Goodwill of Central and Southern Indiana is working to answer these questions with the help of the Indiana University Robert H. McKinney School of Law's Civil Practice Clinic (CPC). Goodwill of
Central and Southern Indiana is one of 161 notfor-profit, independent Goodwill organizations throughout North America that exists to address quality of life and family self-sufficiency issues. Founded in 1930, Goodwill's mission is to change lives every day by empowering people to increase their independence and reach their potential through education, health, and employment. This mission is funded in great part through the generosity of hundreds of thousands of Hoosiers who make financial gifts, donate their clothing and household goods, and shop at its retail stores.

Goodwill executes its mission through an integrated network of direct employment, charter schools, and numerous supportive programs that create opportunities for self-sufficiency. Goodwill operates 78 retail stores, outlets, and distribution centers throughout central and southern Indiana. These facilities employ more than 3,200 people, 59 percent of whom self-report a disability, lack of a high school diploma, and/or a prior felony conviction. Goodwill tracks these three barriers to employment, which often impede those attempting to improve their employment opportunities.

The Civil Practice Clinic (CPC) is an experiential clinical course offered for students of the Indiana University Robert H. McKinney School of Law. The CPC provides legal representation, brief advice, and service to low-income clients on a variety of general civil matters, focusing mostly on criminal expungement. Students in the CPC serve as Certified Legal Interns (CLI), meaning that they may "interview, advise, negotiate for, and represent parties in any judicial or administrative proceeding" 4 under the supervision of an attorney. As part of their CPC experience, students attend weekly classes, complete weekly coursework and

${ }^{4}$ Indiana Rules for Admission to the Bar and the Discipline of Attorneys Rules 2.1 
represent clients in legal proceedings throughout the semester. CPC students work for their clients and the overarching systemic issues on both macro and micro levels by providing free legal representation for individuals, and also by researching and filing briefs as amicus curae on Indiana Supreme Court and Indiana Court of Appeals cases interpreting the laws most impacting their clients.

The corporate office of Goodwill of Central and Southern Indiana is located near downtown Indianapolis in the Hawthorne neighborhood, a mix of private residences and retail/industrial businesses. Within the corporate office space are two charter high schools, The Excel Center (TEC) and Indianapolis Metropolitan High School (IMet), both run by Goodwill. TEC serves adults, and IMet serves high school age students. Just one mile away is the IU McKinney School of Law, where the CPC is located. As the two partners are closely located, classes are held both at the law school and at Goodwill's corporate offices, with space and staff supporting the work of the CPC students for Goodwill's clientele.

\section{THE POPULATION BEING SERVED}

Goodwill employees, students, and program participants - all considered Goodwill Family Members - have the opportunity to work with a Goodwill Guide, someone best described as a life coach. Guides, who are full-time employees, are assigned to specific areas within Goodwill (i.e., retail stores, IMet, The Excel Center, etc.). They work one-on-one with Goodwill employees, students, and program participants to identify strengths as well as challenges while helping them develop paths to success that involve setting career and financial goals.

Guides connect Members with programs and services within Goodwill, such as the NurseFamily Partnership, and other resources. They

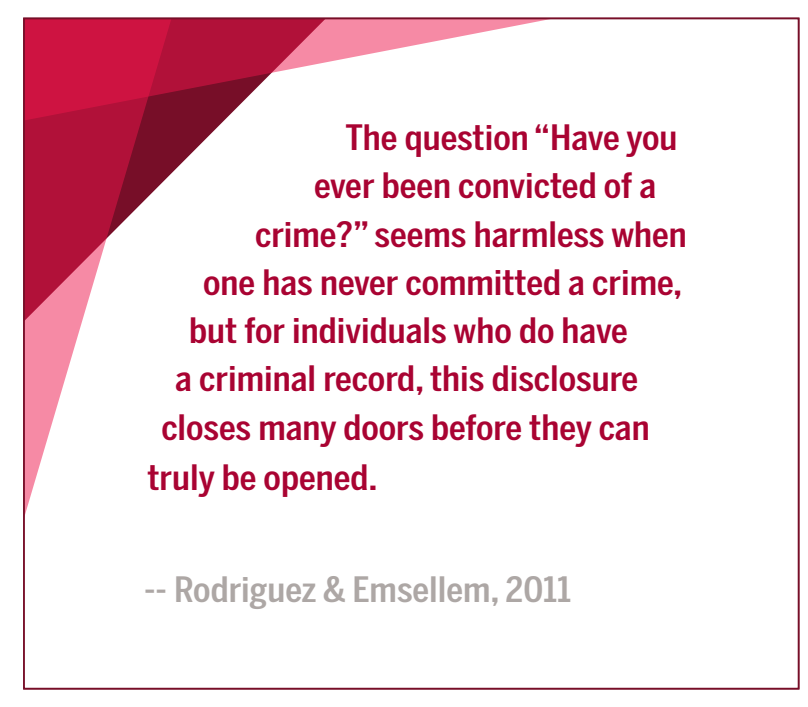

also advocate for and connect Members to services outside Goodwill, such as temporary emergency assistance, housing, childcare, and transportation. Through continued mentoring on skills, including writing a resume and interviewing for a job, Guides also prepare them to pursue career paths with higher earning potential, both inside and outside of Goodwill. According to internal Goodwill data, Guides have provided job services to nearly 2,000 people since 2014. Nearly 1,000 Goodwill Family Members have received a job or promotion while working with Guides since 2013.

Guides and other Goodwill staff have long been aware of how a prior criminal conviction or arrest can be a barrier in the process of empowering people as they make efforts to increase their independence and reach their highest potential. One's criminal history can limit employment and housing opportunities, and in some cases opportunities for higher education.

A recent CareerBuilder study conducted by Harris Poll revealed that 72 percent of employers conduct background checks, and 82 percent are specifically checking to learn if the candidate has a criminal history (CareerBuilder, 2016). Many Goodwill Family Members describe the 
difficulty of obtaining housing, social services, and employment due to having a criminal record. Many say that with a criminal record and limited education and work experience, Goodwill was their only employment option.

Nine percent of Goodwill employees, approximately 361 people, self-report a felony conviction. Goodwill leadership estimates the number of employees with a misdemeanor conviction is even greater. It is reasonable to assume that a similar portion of Goodwill students and program participants have been convicted of a felony or misdemeanor. Accordingly, as many as 2,000 Goodwill Family Members may have a criminal record. Given the above, Guides and Goodwill leadership asked how Members might fare if, having repaid their debt to society years ago, information about their past could be publicly restricted. This led to the partnership with the CPC.

\section{THE PARTNERSHIP AND PROJECT}

In order to file for expungement in Indiana, one must draft several legal documents, including a Petition and a Proposed Order. Both of these documents must list all of the crimes a person is seeking to expunge and provide proof that they meet all legal requirements to file. Litigants are able to expunge all of their convictions only once in their lifetime, and each case must meet all of the requirements to file at the time they petition for expungement. For each case one is seeking to expunge, the required amount of time specified by law must have passed, and all fines and fees owed on each case must have been paid. While the law is fairly clear on these requirements, the process of drafting and filing the paperwork can be a daunting task, depending on how many cases one has and whether those cases are in one or multiple counties.
Given the scope of the legal work involved and the educational and other needs of the Goodwill populations, the partnership, created in 2015 between Goodwill and the CPC, addresses the legal needs involved with expungement. The partnership was initially envisioned as a situation wherein Goodwill could refer anyone the Guides had identified as wanting expungement. It became clear that the majority of those referred were ineligible because not enough time had passed on the cases they were seeking to expunge; they owed fines or fees on the cases they were seeking to expunge; or both. Working together, Goodwill and the CPC decided that, to better serve these needs, a screening project should be offered first, and anyone who was eligible for expungement as identified by that project would be offered representation by the CPC. This project, titled the Legal Expungement Advice Program (LEAP), works directly with and for Goodwill referrals and screens individuals for their eligibility for expungement on a bi-weekly basis during the academic year. LEAP was first launched in the fall of 2016 and is offered every semester, including summers.

To qualify for LEAP, participants are referred by their Goodwill Guides, and identifying information (name, date of birth, etc.) is shared with the CPC so that all criminal records may be located for each referral. Once records are located, each case is screened for its compliance with the expungement criteria, and any red flags (owing fines or fees, not being time eligible, etc.) are noted. Participants are then signed up for a LEAP interview time slot, which is a half hour of brief, one-on-one advice and service by a licensed attorney and certified legal intern (CLI) law student of the CPC. ${ }^{5}$ At that interview, all of the cases found for that participant are

\footnotetext{
${ }^{5}$ Interviews were initially scheduled for an hour, but the CPC and Goodwill found that as staff both at Goodwill and the CPC became better and more adept at screening, the interview times could be shortened to a half hour. Thus more participants are able to be seen during LEAP interview days
} 
discussed, and any new or unknown cases are identified and screened. By the time they leave, each participant knows whether they do or do not qualify for expungement. Two to four weeks following that interview, each participant receives a comprehensive summary letter of everything discussed in that interview. Goodwill Guides, with permission of the Goodwill participants, also receive a copy of the summary letter to assist with any identified needs. In those letters, in addition to an analysis of all cases discussed, LEAP participants receive guidance on how to pay fines and fees; how to find information unavailable online regarding their cases; and have questions about the expungement process answered.

Not only does LEAP provide a valuable service for its Goodwill participants, but the CLI law students at McKinney are able to work with them in a real attorney-client capacity by providing this brief advice and service. At the same time, they fulfill their graduation requirement for experiential learning. CLIs pull all of the criminal records for each referral from the online databases, prescreen each case for eligibility, conduct the LEAP interviews, and draft all follow-up summary letters. Any LEAP participant who is ineligible for expungement is told why they are ineligible and given direction on how to clear the identified legal hurdles to be able to file in the future. For any LEAP participant who is found eligible for expungement, CLI's have the opportunity to take them on as clients for expungement representation, draft all of the paperwork needed to file for expungement, and represent them at any scheduled hearings. CLIs who have worked with LEAP and its participants over the years have self-reported that LEAP has been one of the "most rewarding experiences of [their] law school career" 6 and have appreciated the opportunity

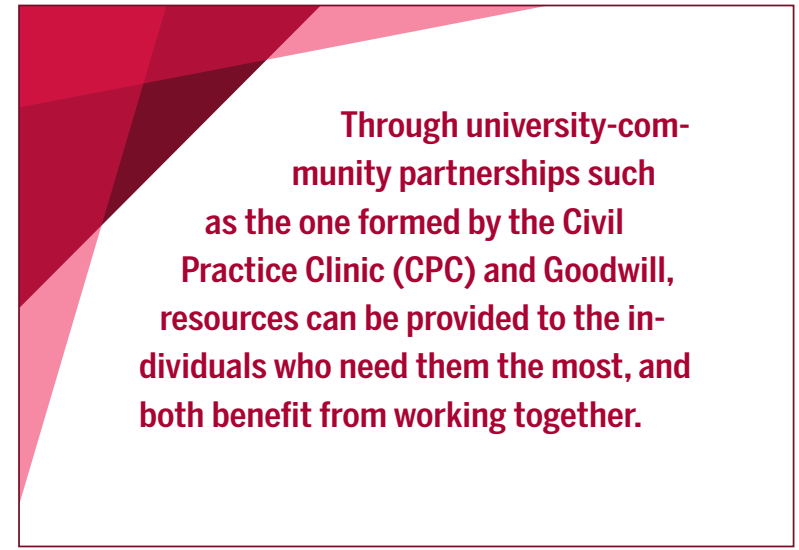

to work with and within an organization like Goodwill. From a pedagogical perspective, CLI students are able to experience crucial lawyering highs and lows by working with LEAP, as they are able to give good news when one qualifies for expungement and must also deliver bad news when letting someone know that they don't qualify, and more often than not, also owe hundreds of dollars in unpaid court costs and fees. Delivering bad news as an attorney is not an easy task but a necessary one, as not every client will hear what they want to hear.

\section{THE REACH}

Since the inception of the project, CPC students have devoted nearly 4,000 hours to LEAP and the resulting client work, and Goodwill has devoted countless hours as well, dedicating two staff to LEAP to collect data, and provide screening, support and referrals.

According to Goodwill's internal data collection processes, as of October 2018, 175 Goodwill participants have been seen by LEAP, with 56 of those participants being eligible for expungement and offered representation. To receive representation, participants must call

\footnotetext{
${ }^{6}$ This comment was taken from a student evaluation of the Civil Practice Clinic experience. Students in the CPC also fill out weekly time sheets, and on the reflection piece of those timesheets, students consistently report highly favorable opinions of working with LEAP and working with Goodwill participants.
} 
the CPC after receiving their summary letter and then retain the CPC as their attorney. The remaining 119 participants who attended LEAP were ineligible for expungement. Forty-four of those 119 owed fines and fees; 19 people were ineligible to file due to time restrictions; and 35 participants were precluded by both fees and time. Twenty-one participants were ineligible for other reasons. Out of the 56 participants who were eligible and received representation, some are waiting for their cases to be filed or for a hearing, and some never called for representation. Nineteen have already been successful in having their records expunged.

To increase community awareness about the barriers involving expungement and to get the local bar of attorneys involved, in the summer of 2017, Goodwill and the CPC partnered with the Professionalism Committee of the Indianapolis Bar Foundation. Through this partnership, LEAP is staffed six times every summer by volunteer and pro bono attorney members of IndyBar. These attorney volunteers receive training on general expungement laws and LEAP protocols, staff the LEAP summer participant interviews, and are responsible for writing the follow-up summary letters. All efforts by IndyBar are supported by the CPC. Just like the CLI self-reports, IndyBar attorneys expressed that working with LEAP is a highly rewarding experience from a volunteer perspective. Volunteer attorneys are eager to repeat the experience for following summer sessions and have also offered to take on eligible participant cases pro bono.

In addition to the above, and after working with Goodwill in identifying that unpaid fines and fees were the most common barrier for LEAP participants, Goodwill applied for an internal grant sponsored by the Goodwill Young Leader's Board in 2018 for $\$ 10,000$, and LEAP was awarded the full $\$ 10,000$. All of the money awarded went towards paying off fines and fees of expungement eligible LEAP participants, and in order to receive those funds, LEAP participants would apply for the funding via a process instituted by Goodwill and the Young Leader's Board. Participants would apply, and agree to personally pay 25 percent of the fine, fees, or penalties they owed, with the grant monies paying the remaining 75 percent. Since the grant award, 24 individuals have applied for funding, and 20 out of the 24 were awarded funding. All grant recipients were then assigned to the CPC for immediate representation, and as of this publication's date, six of the grant recipients have obtained expungement, with the remaining clients in the early stages of filing or awaiting orders for expungement.

\section{CONCLUSION}

By their very status of having a criminal record, persons with a criminal record (PCR) face numerous barriers once they re-enter society. Not only does society judge them based upon their past conduct, but as a result of that judgment, employment is more difficult to obtain. Moreover, access to housing, education, and restoration of civil rights, such as voting, access to guns, and qualifying for public benefits like the Supplemental Nutrition Assistance Program (SNAP) are also limited. With the passage of laws such as Indiana's Second Chance Law, the State of Indiana is recognizing that these barriers exist and providing legal avenues for these individuals to start over. Through university-community partnerships such as the one formed by the Civil Practice Clinic (CPC) and Goodwill, resources can be provided to the individuals who need them the most, and both benefit from working together. Poverty may be a parent of crime, as Aristotle once said, but ingenuity and a passion for helping others through partnerships like LEAP parent new beginnings for persons with a criminal record. 


\section{References}

2014 Ind. HEA 1006.

Blinder, A. (2018). Convicts seeking to clear their records find more prosecutors willing to help. The New York Times. Retrieved from https:// www.nytimes.com/2018/10/07/us/expungement-criminal-justice.html.

CareerBuilder. (2016). More than 1 in 4 employers do not conduct background checks of all new employees, according to careerbuilder survey. Retrieved from https://www.careerbuilder. com/share/aboutus/pressreleasesdetail.aspx?ed=12/31/2016\&id=pr975\&sd=11/17/2016.

CCRC Staff. (2016). 50-state guide to expungement and sealing laws. Collateral Consequences Resource Center. Retrieved from http:// ccresourcecenter.org/2016/01/13/expungement-and-sealing-laws/.

Digest for Court Staff and Clerks. (2017). Retrieved from https://www.in.gov/judiciary/iocs/ files/courtmgmt-expungement-digest-for-courtstaffandclerks.pdf.

Fogle, A. (2018). Expungement 6.0 CLE. [PowerPoint Presentation].
Garner, B. A., \& Black, H. C. (2014). Black's law dictionary. 10th ed. St. Paul, MN: West.

Ind. Code $\S \S 35-38-9-1-35-38-9-11)$.

Ind. Code $\S 35-38-9-3(b)$.

Ind. Code § 35-38-9-6(d).

Ind. Code § 35-38-9-9(i).

Indiana Rules for Admission to the Bar and the Disciple of Attorneys. Rule 2.1 Retrieved from https://www.in.gov/judiciary/rules/ad dis/index.html\# Toc25321527.

Justia. (2018). Expungement and record sealing overview. Retrieved from https://www.justia. com/criminal/expungement-record-sealing/.

National Employment Law Project (NELP). (2018). Ensuring people with convictions have a fair chance to work. Retrieved from http://www. nelp.org/campaign/ensuring-fair-chance-towork/.

Rodriguez, M. \& Emsellem, M. (2011). 65 Million need not apply. National Employment Law Project. Retrieved from www.nelp.org/content/ uploads/2015/03/65 Million Need Not Apply. pdf. 